\title{
¡AHORA SÍ QUE ES PACHALLAMPE! SIMBOLISMO, TECNOLOGÍA Y MEMORIA EN LA SIEMBRA DE PAPA EN SOCOROMA, NORTE DE CHILE 1
}

\author{
NOW IT IS PACHALLAMPE! SYMBOLISM, CELEBRATION AND MEMORY \\ IN THE PLANTING OF POTATO IN SOCOROMA, NORTH OF CHILE
}

\author{
Carlos Choque Mariño y Alberto Díaz Araya ${ }^{1}$
}

\begin{abstract}
El siguiente artículo evidencia las prácticas rituales, significados y memorias expresadas en la fiesta del Pachallampe en Socoroma. Se busca con ello la identificación y comprensión de los ritos y simbolismos desplegados por mayordomos y comuneros indígenas durante la siembra de la papa. Para este efecto se estudia la importancia de la performance, memoria, danza y las dramatizaciones, realizando un análisis descriptivo e interpretativo de la fiesta, identificándose los significados, las asociaciones, identidades y apropiaciones culturales de los socoromeños, derivadas de las interacciones hispanoindígenas y de su relación con las fuerzas antinómicas de su espacio sagrado.
\end{abstract}

Palabras claves: Fiesta, memoria, ritos de siembra, cultura aymara, norte de Chile.

This article shows the ritual practices, meanings and memories expressed in the celebration of the Pachallampe in Socoroma. This, in order to identify and understand the rituals and symbolism deployed by stewards and indigenous community members during the sowing of potato. For this purpose, we have studied the importance of performance, memory, dance and the dramatizations, carrying out a descriptive and interpretative analysis of the celebration, identifying the meanings, associations, identities and cultural appropriations of the Socoromeños, derived from the Hispano-indigenous interactions and their relationship to the antinomic forces of their sacred space.

Key words: Festivity, memory, planting rites, Aymara culture, northern Chile.

Las poblaciones indígenas del área Centro Sur de los Andes, han reproducido a lo largo del tiempo una contundente diversidad de expresiones culturales a través de rituales, asociados al nacimiento, matrimonio y la muerte. Además, existen ritos para la siembra, viajes, corte de pelo o enfermedad, entre otras ceremonias. Para las comunidades andinas, los ritos agrícolas juegan un rol fundamental, ya que la interdependencia y reciprocidad con las fuerzas antinómicas posibilitan la continuidad y subsistencia de la vida, como la producción de las terrazas de cultivo y las chacras comunitarias (Berg1989; Kush 1970; Kessel y Cutipa 1998; Ochoa 1975). Al respecto, existen diversos trabajos etnohistóricos que han estudiado no solo el valor simbólico del maíz, el ají o el trigo, sino que también sus implicancias sociopolíticas y productivas para las economías indígenas, vinculándolas a mercados regionales durante el periodo colonial (Hidalgo 2004; Lacoste 2004; Murra 2002).
Respecto de los ritos de siembra de la papa (Solanum tuberosum Subsp. andigenum), los trabajos etnográficos, principalmente desarrollados en Bolivia y Perú han interpretado que existirían vínculos semánticos entre el cultivo de papas (denominándola "crianza de la papa") y la cosmovisión de los indígenas aymara (Kessel y Larraín 2000). Asimismo, algunos autores asignaron atributos a la papa andina como parte de arquetipos femenino/fertilidad y masculino/guerrero (Arnold y Yapita 1996; Rosas 1989). Igualmente, existen indagaciones relativas a las ceremonias y construcción de identidades comunitarias sobre la base la producción de la papa (Corrales 2004; Plata 2009). Para el caso del norte de Chile, los trabajos de Álvarez (1987), Mamani (2002) y Luque (2009) ofrecen una introducción al conjunto de rituales de la siembra de la papa que se practican en las comunidades aymaras en la sierra o precordillera de Arica $^{2}$. Sin perjuicio de lo anterior, y teniendo en consideración que los ritos

1 Departamento de Ciencias Históricas y Geográficas, Facultad de Educación y Humanidades, Universidad de Tarapacá, Arica, Chile.cochoquem@uta.cl; albertodiaz@uta.cl 
son una secuencia de actividades que involucran "gestos, palabras y objetos, realizados en un lugar secuestrado, y diseñado para influir en entidades sobrenaturales o fuerzas a favor de los objetivos e intereses de los actores" (Turner 1977a:183), resulta de interés analizar cómo los aymara de la sierra de Arica en el extremo norte de Chile, realizan una serie de ceremonias y ritos denominado localmente como Pachallampe o Pachallampi, y en el cual se ejecuta un repertorio ceremonial donde interactúan los comuneros, los sistemas de cargos religiosos ("mayordomos"), y las imágenes de los santos patronos, entre cánticos, instrumentación musical y danzas, desplegando una serie de símbolos religiosos y rasgos de la estructura social de la comunidad de Socoroma (Berg 1989; Choque 2015; Díaz 2014).

Socoroma se encuentra en la sierra de Arica a una altura de $3.200 \mathrm{msm}$, zona ecológica precordillerana donde predominan accidentes orográficos, prevaleciendo paisajes de cerros, quebradas y andenes. Los miembros de la comunidad de Socoroma son aymaras, que debido a los diferentes procesos históricos ocurridos durante el siglo XX en la Región de Arica y Parinacota, como fueron la "Chilenización" de la zona tras la guerra del Pacífico, la incorporación de la población indígena al mercado laboral, la creación del "Puerto libre" y "Junta de Adelanto de Arica" a mediados de siglo, lo que gravitó la migración de los comuneros hacia el puerto ariqueño, han experimentado una serie de transformaciones sociales y culturales al interior de la comunidad, articulando la membresía comunitaria entre la residencia en el poblado como en las ciudades nortinas (Choque 2013; Díaz 2011; Gundermann 2004; Muñoz y Choque 2013) 3 Del mismo modo, dichos procesos históricos, como también el advenimiento de las Iglesias evangélicas, fueron relegando algunas costumbres y ceremonias vinculadas a la papa, tal como ocurrió con las comunidades precordilleranas de Tignamar, Saxamar o Cobija (Figura 1). Si bien algunos de los vecinos de Socoroma, como de las localidades de Putre, Belén y Pachama se han visto afectados debido a la migración, siguen practicando los ritos supeditados a las funciones de los mayordomos, para asegurar la productividad de la papa en los Andes chilenos.

Este artículo se concentra en el análisis de una serie de antecedentes etnográficos que nos permiten describir la complejidad ritual para la siembra de la papa en una comunidad andina del norte chileno, estudiando la organización del rito del Pachallampe, la puesta en escena de los comuneros que buscan a través de las ceremonias, la musicalización y despliegue coreográfico, asegurar la fecundidad de los campos precordilleranos. En este contexto, planteamos que la práctica comunal del Pachallampe al vincularse al inicio del calendario de celebraciones, permite aminorar las tensiones internas comunitarias, actuando como un vector de congregación social. Asimismo, las performances y procesiones de imágenes religiosas de los Santos y la Virgen hacia las áreas de cultivos, permiten actualizar en un lugar común, las memorias sociales en un contexto ritual, donde confluyen e interactúan los distintos linajes de la comunidad de Socoroma (Figura 2).

\section{La Papa y sus Significados}

Los estudios etnográficos realizados en Perú y Bolivia, coinciden en mencionar que la papa posee un origen mítico expresado en el relato de las hermanas Namca y de Mama Raywana (Robles 2007; Sandoval 2011 $)^{4}$. Este tubérculo simbolizaría la vida, ya que canaliza la fecundidad, al poseer un carácter elemental de materia y energía, siendo además una unidad original de subsistencia e interacciones espaciales (Graves 2006). Asimismo, es una entidad del mundo subterráneo, que vincula a este espacio Aka pacha con el Mundo de abajo Manqha pacha ${ }^{5}$, generando una permanente vigencia de la ideología andina de la regeneración, pues cobija en su seno la humedad, manteniéndose dormida hasta el momento ritual que facilita su germinación (Choque 2013; Sánchez 2013). Por ello, este tubérculo solo puede germinar en la oscuridad del manqha pacha, siendo impropio que los espíritus de la papa surjan fuera de su tiempo, pues solo generarían malas cosechas y la pérdida de los productos almacenados en las colcas o depósitos subterráneos.

En términos semánticos, Arnold y Yapita (1996) sostienen que en la cosmovisión andina, la papa posee una taxonomía espiritual compleja, expresadas en tres almas similares a las humanas, como son axaju, janayu y el espíritu (Arnold y Yapita 1996; Choque 2012a), siendo los espíritus primordiales o ispallas (espíritu de los productos agrícolas), jerarquizadas de mayor a menor y ubicadas en diferentes dimensiones físicas y espaciales de la planta ${ }^{6}$. Del mismo modo, la papa, a decir de las conjeturas de Rosas (1989), se constituye como el arquetipo "femenino andino -la papamama, siendo un almacén de energía que, 


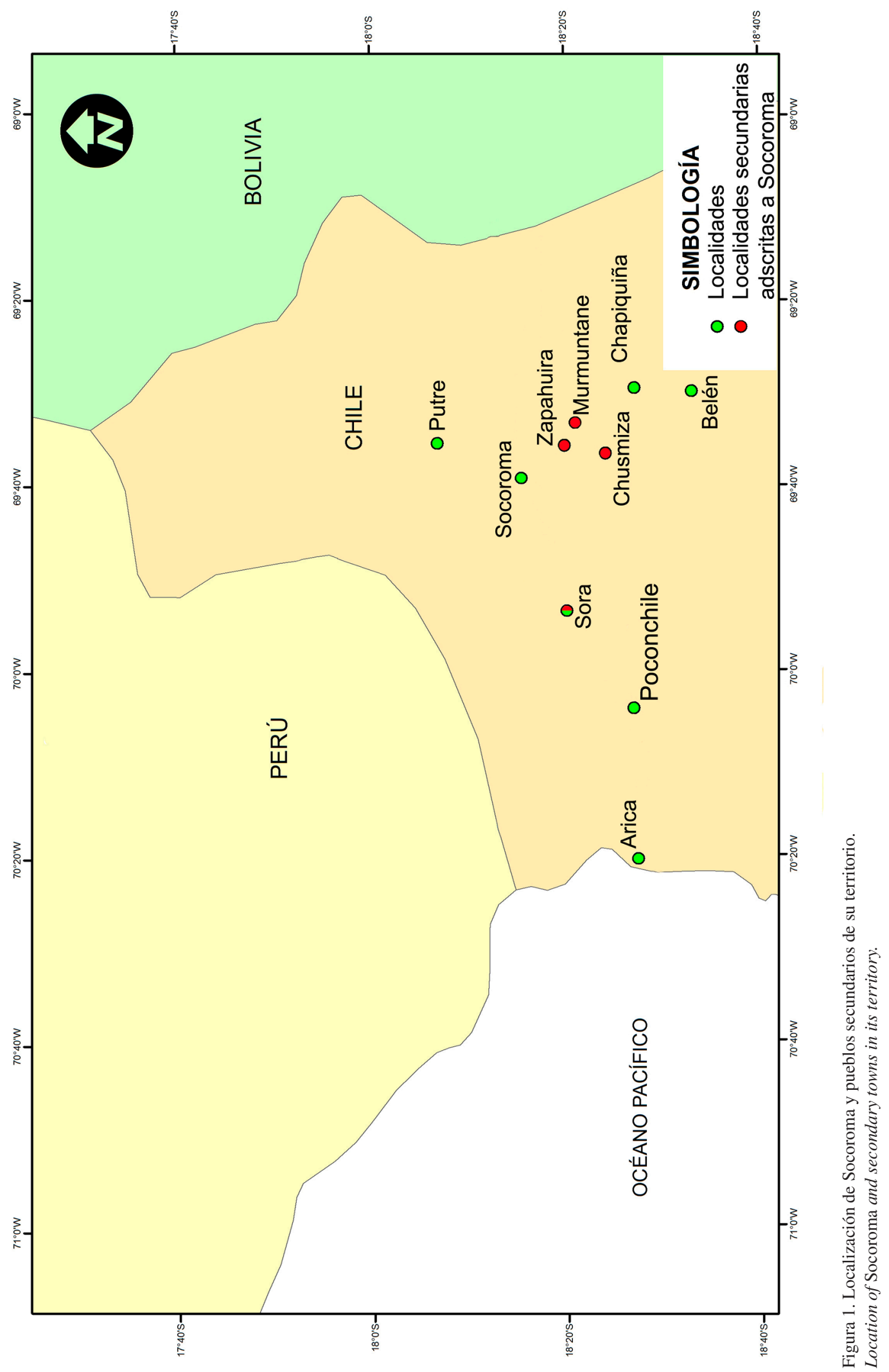




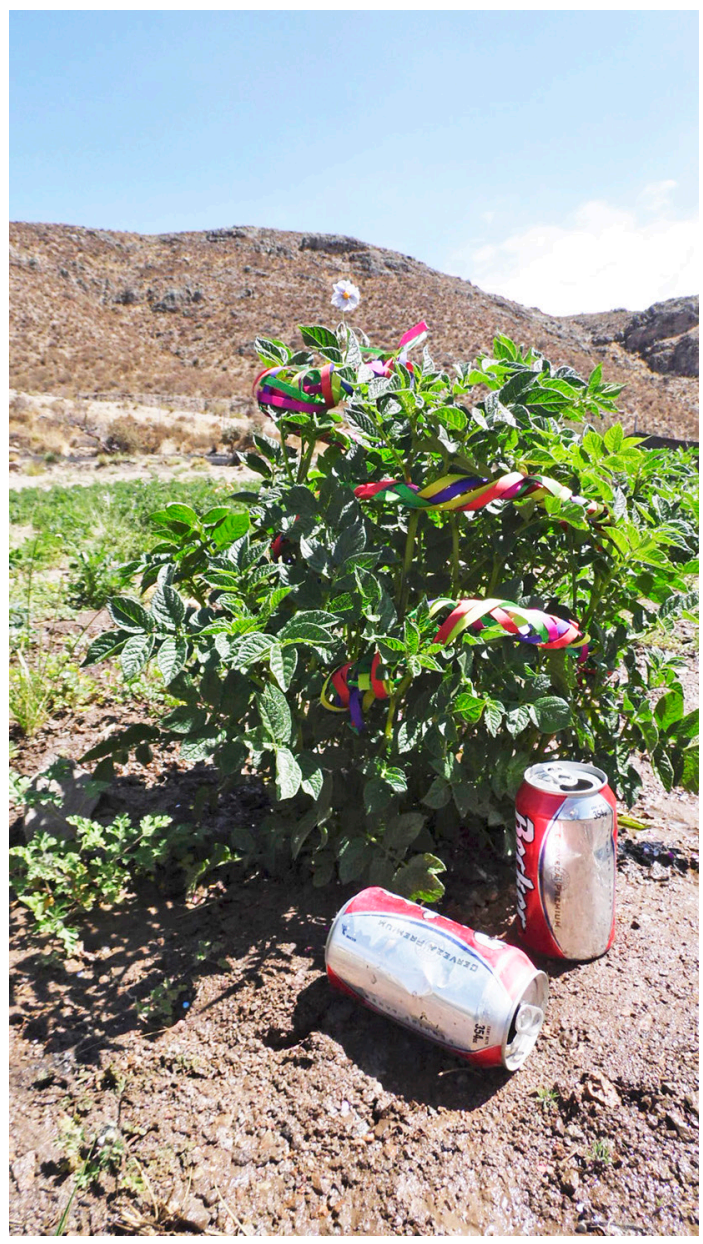

Figura 2. Planta de papa decorada en el día de Martes de Ch'alla con serpentinas y cervezas.

Potato plant decorated on the Tuesday of Ch'alla with streamers and beers (Choque 2016).

como la luz de las estrellas que ella personificaría, actúa como "el cinturón de Orión, que crece y decrece, y en relación al agua logra transformación" (Rosas 1989:12). Igualmente, su simbolismo en la cosmovisión andina no solamente se asocia a la vida, sino también a la fecundidad y seguridad económica de las comunidades campesinas, por ello soñar con este vegetal es también augurio de prosperidad y bienestar (Buechler y Buechler 1971). En tales circunstancias, y de acuerdo a las creencias, los comuneros procuran establecer una relación de armonía y entendimiento con estos espíritus, a fin de ser favorecidos con buenas cosechas (Choque 2013; Fernández 1995; Graves 2006; van Kessel y Larraín 2000).
Respecto a los aspectos rituales, los cronistas Cieza y Poma de Ayala, evidencian la existencia de ritos de la Papa Tarpuy o siembra de papa (Figura 3) ${ }^{7}$. Este tipo de rito o "festejo a la tierra con cariño", como lo define Mamani (2001:46), tiene la finalidad de reafirmar los lazos de reciprocidad entre el hombre andino y las deidades, para lo cual se entregan dones y ofrendas, cuyo resultado será una cosecha más próspera y la propia armonía de la comunidad en los tiempos de precosecha y cosecha, ya que los frutos obtenidos pertenecen a las imágenes sagradas y deidades comunales. Por ello, esta fiesta posee una dimensión simbólica y ritual, que juegan un rol transcendental en los pueblos andinos de la sierra y puna, tanto por sus aspectos económicos, religiosos e identitarios. En consecuencia, se produce una sucesión de performances en los ritos propiciatorios, que están dotados de simbolismos y significados jerarquizados e interrelacionados activamente en el imaginario colectivo de los socoromeños, ya que la papa les permite el acceso al prestigio comunal,

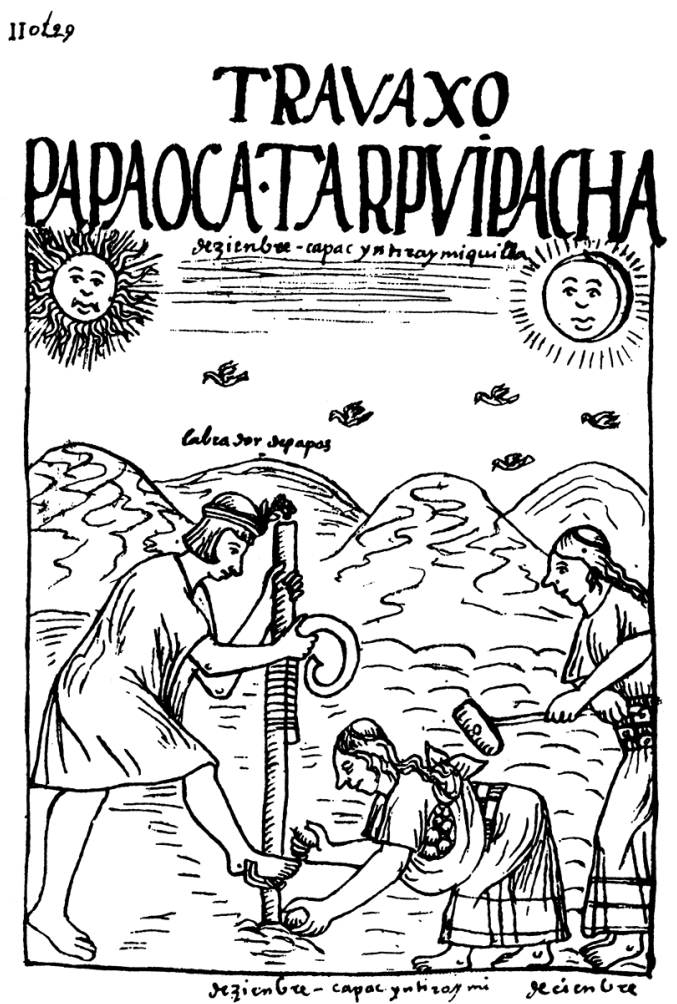

Figura 3. Tiempo de sembrar papas y ocas en la obra de Guamán Poma de Ayala .

Time of sowing potatoes, and geese in the work of Guamán Poma de Ayala. 
la fecundidad de los suelos y una vinculación permanente con el espacio sagrado.

\section{La siembra de la papa. Ritos propiciatorios, escenificaciones, tecnologías y simbolismo}

En el caso de Socoroma, el Pachallampe, fue realizado en décadas pasadas por todos los mayordomos de la iglesia, es decir, San Francisco, Crucificado, Virgen del Rosario, Carmen, Candelaria y Santa Lucía ${ }^{8}$, una fiesta que duró seis días, uno por cada mayordomía, agregándose un séptimo día, para el "remate" comunal o walichave (Figura 4)9. En la actualidad, la fiesta solo la realizan los mayordomos mayores de San Francisco y la Virgen del Rosario y Carmen. Los ritos propiciatorios se inician al finalizar la cosecha de papa en mayo, ya que los campesinos deben seleccionar la semilla, que será utilizada en noviembre; preparar la chicha de maíz y elaborar los artefactos para las ceremonias. La selección de papas y semillas obedecen a un criterio taxonómico, pues el tubérculo debe poseer la suficiente cantidad de "ojos" o "yemas vegetativas", que aseguren la formación de los tallos. Este periodo de selección de papas coincide además, con la celebración de las cruces de mayo y San Isidro, siendo este el momento donde los ritmos de $k_{u k u l i}{ }^{10}$ dan paso a canciones y coplas de Pachallampe, el 15 de mayo de cada año.

En Socoroma, las campesinas suelen tomar y besar aquellas papas que poseen gran cantidad de ojos, diciendo: "hay mamita, tan linda, tan preciosa. ¿Cuántas wawas tendrás para el año?" (Justina Mariño, 65 años). Dichas expresiones no son únicas del territorio de estudio, pues también se han registrado expresiones similares en el Cusco y Apurímac en el Perú y el altiplano de Bolivia (Arce 2014; Valderrama y Escalante 1993). Acto seguido dichas semillas son cuidadosamente enterradas en almacenes subterráneos, construidos en áreas cercanas al cultivo hasta las vísperas de la siembra. Un segundo momento de preparación del Pachallampe es la elaboración de chicha ${ }^{11}$. El consumo de la bebida libatoria fue masivo hasta la década de 1990, por tener amplias connotaciones rituales y sociales (Hayashida 2008; Jennings y

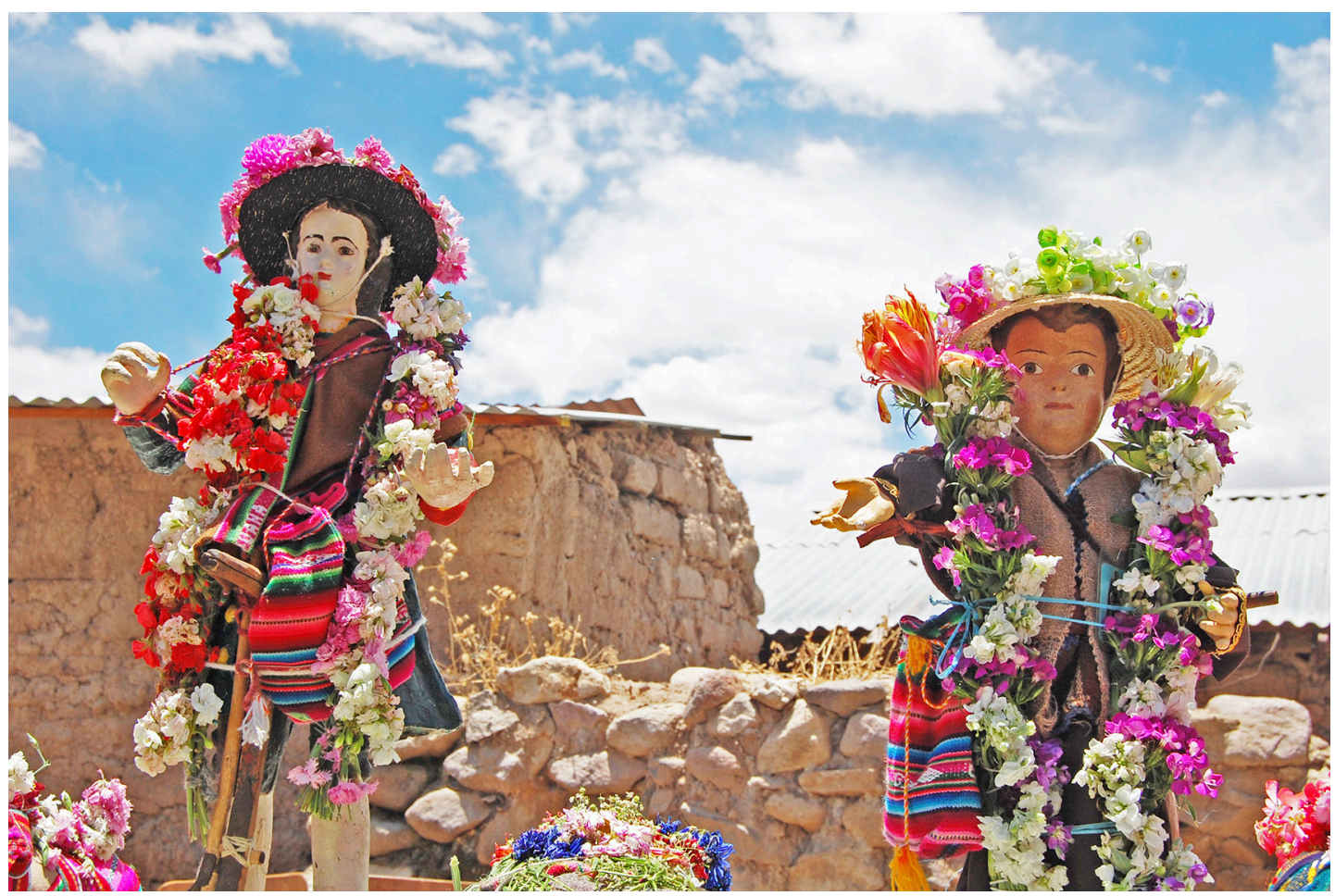

Figura 4. San Isidro Labrador y San Salvador, los santos pachallamperos. Saint Isidore the Farmer and Saint Salvador, the Holy pachallamperos. 
Bowser 2008; Pacheco 2014). Sin embargo, en las últimas décadas su elaboración y uso ha sido más simbólico, pues se la ha reemplazado por el vino, cerveza y licores destilados. La preparación de chicha de maíz constituyó un evento social y cultural que convocó a adolescentes y mujeres solteras durante algunos días de agosto o septiembre, siendo una acción que integraba y legitimaba a los integrantes de la comunidad. La variedad de maíz (Zea Maiz L.) Chilpe se empleaba por ser un grano rico en azúcares, hecho que posibilita una buena fermentación. La elaboración de la chicha, se inicia con el tostamiento o jimp' $i$, que luego es macerado por mujeres jóvenes, actividad que recibe el nombre de khistuña o khistiña ${ }^{12}$, que es realizado en un ambiente festivo (Choque 2012b; Medrano 2007). El producto de la salivación y el maíz, es almacenado en ollas o lavatorios que posteriormente son vaciados en una gran tinaja de barro, donde se somete a cocción por unas seis u ocho horas, agregándosele agua y azúcar, este último para acelerar la fermentación. A partir del tercer día la bebida puede ser consumida a pesar de tener una baja graduación de alcohol. Fue costumbre, entre los mayordomos y alférez, solicitar la ayuda del "pregonero", quien desde el "Chorro de Tara" en el alto del pueblo invita a las adolescentes y jóvenes con el siguiente pregón: "Pasar a la casa del señor mayordomo a retirar la chicha para el desayuno" (Teófilo, 85 años). En este contexto, las jóvenes acudían a la casa del mayordomo con sus jarras y ollas a buscar chicha para el desayuno, reafirmando así los lazos de reciprocidad comunal entre las chicheras y las mayordomías, revalidando además la relación y comunión con las divinidades, que exigen chicha para ciertos ritos agrícolas (Choque 2012a; Pacheco 2014) ${ }^{13}$. En décadas pasadas también se usó el vino Pintatani por su valor simbólico y ritual ${ }^{14}$, siendo traído desde Livilcar o Codpa por los propios socoromeños o "viñateros codpeños" que viajaban en octubre para vender sus mejores vinos en Socoroma, Belén o Putre ${ }^{15}$.

Finalmente, los mayordomos elaboran artefactos rituales con una copiosa cantidad de flores de retama, claveles o clavelinas, confeccionando coronas de flores o "pillos" que sirven para decorar los animales de carga, los sombreros de los ch'onteros $^{16}$, las sembradoras y los santos Pachallamperos, que concurren a la siembra. La elaboración de los pillos es realizada con un despliegue de música y consumo de chicha, vino o cerveza, luego del llamado de las campanas y los "tiros" o "bengalas" 17 . El significado del pillo se asocia al florecimiento de los campos y a la garantía de fecundidad de las flores de papa (Berg 1989). La escenificación e interacciones se producen cuando los participantes han culminado la elaboración de los pillos, disponiendo de las semillas, "chontas" y fiambre, sobre un altar temporal, todo ello en medio de libaciones y consumo de comida, que culminan con la detonación de nuevos "tiros", que convocan la venida de los demás mayordomos. En el caso de hacer entrega de la mayordomía y semillas de papa, el mayordomo "saliente" solo podrá, convocar a las autoridades religiosas una vez que el "entrante" ha realizado su Ch'alta y después del estruendo de sus "tiros"18. La Ch'alta se realiza respetando el sistema de jerarquización del espacio sagrado de los socoromeños, es decir, es iniciado por el fabriquero o en su defecto por el mayordomo mayor, realizando una secuencia libatoria que convoca a las fuerzas antinómicas de la comunidad (Choque 2009). Una vez concluida la Ch'alta, los mayordomos acuden a la iglesia en busca de las imágenes sagradas que participan en la siembra ritual: San Isidro (cargo de San Francisco), San Salvador (cargo de Candelaria) y los "niños" de la virgen del Rosario, Carmen y Santa Lucía, dichas imágenes deben salir bailando de la iglesia hasta la casa del mayordomo, al ritmo de música de Pachallampe, que es interpretada con instrumentos de cuerda (guitarra, violín y acordeón) por tres o cuatro músicos del mismo pueblo y por el baile escenificado de los mayordomos (Figura 5). La música, según Mamani (2002), juega un rol relevante en los festejos y como elemento socializador por excelencia, ya que va guiando el proceso ritual. La música tiene una razón de ser dentro de los rituales andinos y gracias a su cualidad estética convoca a las fuerzas antinómicas y a los comuneros para interactuar con ellos, y la propia interacción musical implica una mayor efectividad y fluidez en las relaciones simbólicas con las deidades. Por ello, las melodías y versos se emiten sobre un tono mayor de compás binario simple $2 / 4$ y en cuartetas, enriquecidas con relatos afectivos hacia la mujer, la papa, la comunidad, los mayordomos y el espacio sagrado. Dicho canto ritual posee algunas semejanzas con el estilo de las wankas ${ }^{19}$, pues las estrofas de introducción enuncian características melódico-rítmicas que se repiten en cada verso y estrofa (Arce 2014). 


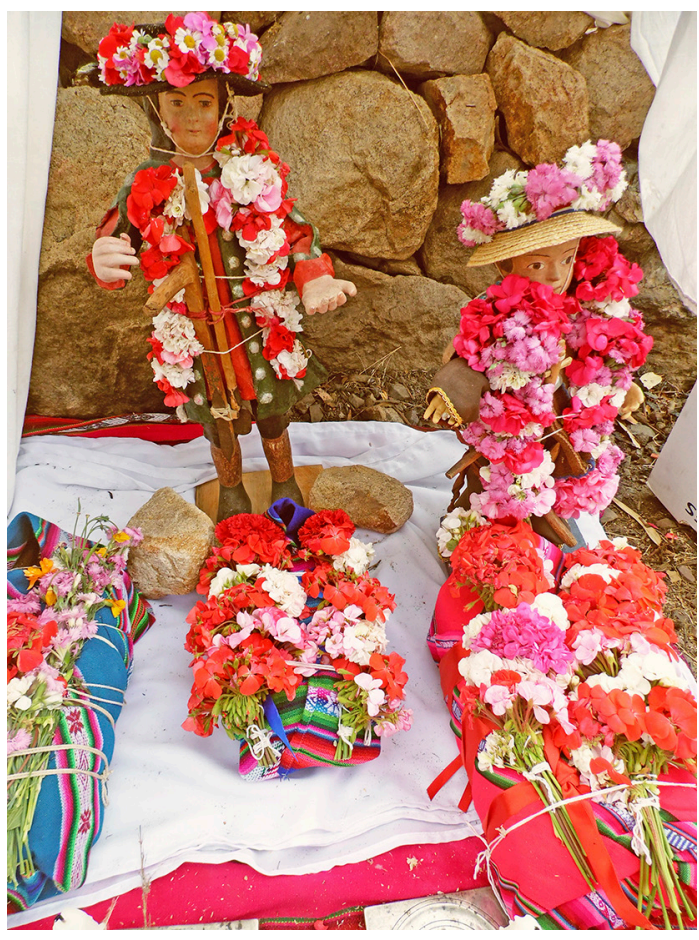

Figura 5. San Isidro, San Salvador y los niños de la virgen del Rosario, Carmen y Santa Lucia.

Saint Isidore, Saint Salvador and the children of the Virgin of the Rosario, Carmen and Saint Lucia.

La escenificación llevada a cabo por los mayordomos en la plaza, consiste en ubicar espacialmente a cada mayordomo según el prestigio y simbolismo de cada imagen sagrada, así el baile se convierte en una forma de dramatización que sitúa los cuerpos de los sujetos en tiempos y espacios distantes, que van bailando, reproduciendo letras, coreografías sincronizadas y memorias metaforizadas de tiempos lejanos, que vuelven a ser vivenciados o rememorados a medida que se baila frente a la iglesia (Choque 2012b). Situación, que se vuelve a reproducir en casa del celebrante. Al existir mayordomo "entrante", este se dirige con las imágenes a la zona de cultivo seguido discretamente por el "saliente", junto a la otra mitad del pueblo. Los diversos ritos propiciatorios, como la selección de la semilla, la elaboración de la chicha y preparación de pillos, constituyen una expresión simbólica y tecnológica que prepara a la comunidad para los ritos centrales, que serán dramatizaciones colectivas, no exentas de tensiones, pues con ello los celebrantes acuden al encuentro recíproco de sus deidades (Díaz 2011) ${ }^{20}$. Además, esta procesión y danza permiten memorizar a la comunidad la estructura societal de las diversas autoridades religiosas y linajes participantes en el Pachallampe. En tales circunstancias, se asume que la tecnología es un fenómeno que liga lo material, lo social y lo simbólico, definiéndola como una red de asociaciones y tejidos sociotécnicos que adquiere una relación biológica con los comuneros andinos. En síntesis, la tecnología occidental colonial se convirtió en parte de los sistemas culturales de los andinos, que la reinterpretaron para sus propias necesidades y realidades culturales, expresándolas luego en los despliegues rituales de la siembra de la papa.

\section{Procesiones, bailes y performances durante la siembra de la papa}

El Pachallampe es realizado en chacras de las imágenes sagradas que fueron previamente preparadas en octubre ${ }^{21}$. Los trabajos son sencillos, consistiendo en el barbecho de los terrenos, la reparación de canales y nivelación de los suelos. Al tratarse de terrenos destinados a la siembra de papa de las imágenes, los mayordomos deben disponer de ofrendas simples para iniciar la limpieza de los suelos, dichos ofrecimientos son de q'uwa (Diplostephium cinereum), Unt'u (sebo extraído del pecho de la llama) ${ }^{22}$, hojas de coca (Erithroxilum coca), alcohol y vino, que son ofrecidos a la Pachamama y Achachilas sobre un brasero ${ }^{23}$. $\mathrm{La}$ siembra de papa se realiza preferentemente en el sector de Aroma $^{24}$, sitio ubicado a $2 \mathrm{~km}$ del pueblo ${ }^{25}$, exigiendo una reproducción permanente de ofrendas de música y danza, que es realizado por las seis parejas de mayordomos frente una audiencia comunal y espacio sagrado (Choque 2009) ${ }^{26}$. En este contexto ritualizado, los participantes ejecutan su danza en un sitio específico llamado $K^{\prime}$ otaña ${ }^{27}$, focalizando la atención de los acompañantes, ya que no solo están bailando, sino además haciendo mención a memorias olvidadas, que son vueltas a recobrar en los campos metafóricos y narrativos en medio de una permanente libación (Gavilán y Carrasco 2009).

En un trabajo anterior (Díaz 2011), consideramos que las procesiones fueron barómetros que permitieron tomar el pulso al comportamiento y posición de los danzantes en la estructura social durante la Colonia, además de formar parte de un acervo religioso público (Díaz et al. 2012) ${ }^{28}$, hecho que no ha cambiado en las comunidades campesinas, ya que la rigurosidad del protocolo y jerarquía entre los mayordomos son cuidadosamente vigilados por 
el fabriquero y la comunidad en general (Choque 2012, 2015). Las transgresiones a este orden preestablecido no se manifiestan, ni siquiera al inicio de la celebración del Pachallampe, pues el "entrante" ordena e instruye a los "servicios" las instrucciones finales antes de iniciar la celebración central ${ }^{29}$. Las prácticas performativas deben ser entendidas como la reproducción peculiar y vigorosa impresión de la realidad, que es capaz de despertar emociones "intensas y vividas que no se suscitan solo en las situaciones reales" (Trueba 2002:36). Además, esta performance posee la capacidad de crear continuidades con el pasado de los socoromeños, siendo los ritos un catalizador que remite a la memoria, acontecimientos de tiempos míticos por medio de representaciones dramáticas del pasado (Connerton 1989; Choque 2013; Eliade 2001).

La performance se evidencia en tres momentos consecutivos; la aparición del negro y el capataz, la entrega de la semilla del mayordomo "saliente" al "entrante" y la siembra de la papa ${ }^{30}$. La primera escena se inicia en casa del mayordomo, quien debe tener un comunero que ejerza la función del negro que arrea los animales y otro como "capataz" o "patrón”, que está encargado de proteger la carga de los bandidos. Así, la relación entre los actores y su papel expresan orden y jerarquía, siendo una expresión de la alteridad tardocolonial, tal como lo evidenció Gisela Canepa en su estudio en Paucartambo y Manuel Mamani en Pachama ${ }^{31}$. Estas experimentaciones y dramatizaciones buscan la interpretación de roles antagónicos de la identidad y estructura social. El comunero que lleva las mulas y burros es previamente pintado con hollín, dicha máscara simbólica le permite expresar de manera fiel su representación. Además, el uso de la máscara busca expresar los arquetipos e identidades remotas del espacio sagrado de los socoromeños y la subalternidad de los mismos. Es decir, el comunero enmascarado al igual que los chiriguanos "Chané" despliegan "una representación sagrada del pasado, que se personifica, materializa en lo ritual" (Bossert y Villar 2006:63). Esta asociación con el pasado tiene como escena previa la fiesta de los "Santos difuntos" que es realizada en los días previos al Pachallampe, siendo obligatorio realizar la siembra ritual, que se realiza después de los ritos funerarios del 1 y 2 de noviembre. Así, el negro encarna las fuerzas sagradas de los Achachilas y el pasado remoto de los socoromeños, que han sido subalternizados en el periodo colonial.
Por otra, parte el "capataz" tiene una oposición religiosa y social al negro, ya que simboliza a la sociedad hegemónica, sus valores morales y culturales, convirtiéndose en los arquetipos de aspiración colectiva de las sociedades andinas desde el periodo colonial ${ }^{32}$. Por ello, representar al capataz involucra también el despliegue de prestigio al interior de la comunidad, a diferencia del "negro" que ejerce un rol subalterno, doblegado y en permanente mutismo, y por ende, motivo de burla y escarnio festivo. La representación del capataz, vestido con poncho de vicuña, sombrero de paño plomo, polainas de cuero, espuelas y estribos de plata, montado sobre un caballo negro, simbolizan el orden social y religioso instaurado por el cristianismo en el espacio sagrado andino, legitimando los ideales o normas de conducta de las clases dominantes y hegemónicos que se imponen sobre el "negro". Las representaciones además están acompañadas del baile del negro, el jinete y las cabalgaduras, que tienden a construir un ambiente ritualizado performatizado, que interactúa como opuestos complementarios de lo andino y lo hispano. La segunda escena, se manifiesta cuando la procesión de mayordomos, "capataz", "negro" y comunidad llegan a la zona de cultivo. Tras el baile ritual de introducción se instalan las imágenes religiosas en un altar temporal, para luego proceder a formar dos "ruedas" de danzantes que comienzan a bailar de manera simultánea, expresando así la existencia de la dualidad complementaria del "entrante" y "saliente". De la misma forma, los músicos despliegan toda su capacidad narrativa y melódica, entonando versos que fortalecen las prácticas sociales y rituales de la comunidad. La coreografía danzada y la música proponen un contexto ritual que rememora tiempos pasados y contextos históricos más amplios, pues surge una permanente interacción y negociación de ambos grupos y audiencia en general (Canepa 2001). Asimismo, dicha escenificación posee una dimensión política colectiva, que reafirma la identidad entre los socoromeños. La entrega de la semilla, en este contexto, se convierte en un acto central, iniciándose la entonación de la siguiente canción a modo de obertura (Figura 6).

Acto seguido, los "servicios" colocan los costales de papa sobre una "balanza romana"33, procediéndose a pesar la papa, para luego pesar al "negro", que debe igualar el peso de los tubérculos, introduciéndose hojas de coca en la lliclia o lliclla que lleva en la espalda ${ }^{34}$. Igualmente, algunos comuneros 


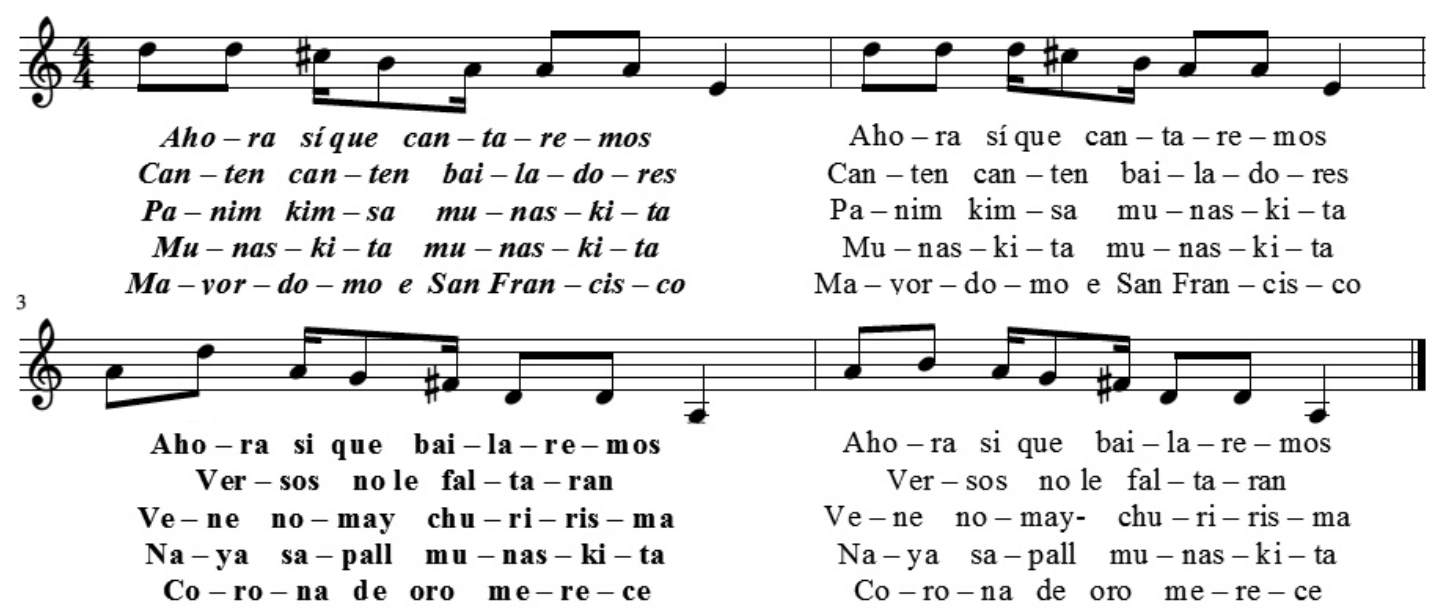

Figura 6. Partituras musicales del Pachallampe.

Sheet music of the Pachallampe.

suelen colocarle piedras para igualar el peso a modo de broma. El uso profuso de chicha y licores suelen generar un contexto ritual que es seguido de "vivas" al mayordomo saliente. Posteriormente, los "servicios" disponen de las papas sobre mantas, para seleccionar solo las semillas en buen estado. La escena siguiente es la Ch'alta de semillas de la virgen o santo, debiendo los mayordomos entregar su ofrenda libatoria según su posición jerárquica. $\mathrm{Al}$ centro de la papa se coloca una botella de licor ricamente adornada con flores, que recibe el nombre de "pichuncho", que solo puede ser consumido al momento de iniciarse la cosecha, en mayo. La escena tiene además a las mujeres suplicando a las semillas de papa, para que exista fecundidad de los campos y a "no dejarse llevar por las plagas" (Berg 1989:54).

Los ritos de libaciones sobre la papa fueron documentados por Pedro Cieza de León, según Murra, ya que "el príncipe de los cronistas españoles" conversó con un sacerdote europeo, quien permitió una ceremonia de siembra de papa, donde hubo música y danzas con instrumentos agrícolas y "cierta actitud competitiva entre las dos parcialidades. Se sacrificó una llama y semillas grandes y escogidas de papa fueron bañadas en sangre" (Murra 2002:148). En la actualidad, la Ch'alta de las semillas no es realizada con sangre de animales, pero a medida que la actividad libatoria aumenta, fue común el surgimiento de tensiones y conflictos entre los participantes, que no dudaban en darse de golpes hasta sangrar, produciéndose así la ofrenda simbólica de sangre de los propios comuneros a las deidades locales. La última escena de la performance requiere de la asignación de tres escenarios distintos: el de los santos, los mayordomos y los sembradores. El primer espacio contiene las imágenes religiosas que están decoradas con flores y mantas, además de poseer lámparas de plata y braceros con incienso, cuyos destinatarios son ubicados según su posición jerárquica. El segundo espacio está reservado a los mayordomos en igual orden y; el tercero, a los sembradores o Ch'onteros.

El cronista indígena Guamán Poma denominó a esta fiesta como papa uqa tarpuy pacha (Poma de Ayala 1992:1063), recibiendo en la actualidad el nombre de Papa Tarpuy en el Perú y Ch'oqe Sata en Bolivia. La diferencia entre el Papa tarpuy y el Pachallampe está dada por la música y los comensales sagrados invitados, que varían según las realidades regionales. En el caso de los departamentos de Huancavelica y Junín, el acompañamiento musical es realizado al ritmo de quenas y tambores, no faltando las jarras de chicha, la hoja de coca y otros artefactos de uso ritual (Graves 2006). En las comunidades cusqueñas, puneñas y tacneñas la música es proporcionada por instrumentos de cuerdas y acordeones ${ }^{35}$. Al igual que el Pachallampe, los significados y los simbolismos tienen el mismo fin, buscar el consentimiento de los Achachilas o Apus, para la cosecha benigna de las papas del panteón religioso comunal. Si bien la musicalización en Socoroma, Putre y Pachama ${ }^{36}$, se realiza con instrumentos de origen colonial, la finalidad es la misma, pues la aculturación, trajo 
consigo la andinización de las tecnologías hispanas, que se adaptaron a las necesidades de las comunidades andinas (Figura 6).

La ubicación jerarquizada de las parejas de mayordomos, seguidos por laritas, awantiri, lojo o "arriero" y kullakas $^{37}$, dan inicio a la siembra ritual, que toma características competitivas entre los diferentes mayordomos que tratan de terminar los espacios asignados antes que sus acompañantes, aumentando con ello el prestigio de la imagen religiosa que representan y el linaje de origen. Por ello, los hombres tratan de hacer un uso infructuoso de la Ch'onta y sus mujeres les siguen colocando las semillas de papas en los orificios, para luego cubrirlos con terrones de tierra. La función, que desarrollan los otros actores es asistencial y juegan un rol secundario en el rito (Figura 7). En suma, el despliegue performático que realizan los campesinos de Socoroma viene a evidenciar la relación binaria y complementaria de su identidad aymara y mestiza, que recurren a sus deidades andinas y las imágenes religiosas cristianas para asegurar la fertilidad y abundancia de sus chacras. Además, la propia danza, es un esfuerzo de vinculación con la identidad, así las coreografías tienden a reproducir vivencias pasadas que son añoradas y representadas con dramatismos colectivos (Figura 8).

\section{Memorias e interacciones de identidad en el Pachallampe}

La "identidad" consiste en el reconocimiento y aceptación de la propia personalidad del "yo", que se expande socialmente entre los sujetos que se sienten parte de un determinado grupo de referencia. Por ello, la identidad no se pierde al cambiar los sujetos de espacio territorial. Avtar Brah, estableció que la construcción de la "identidad está determinada por experiencias construidas culturalmente, en relaciones sociales, creando identidades colectivas" (Brah 1996:126). Dicha afirmación fue previamente postulada por Stuart Hall, quien la consideró como una construcción elaborada con discursos, prácticas y posiciones diferentes, no siendo además unificadas, sino más bien "fragmentadas y fracturadas" (Hall 1990:17). En este contexto, los socoromeños consideran que sus "costumbres" constituyen la autorrepresentación de su cultura, que es dignificada por la actuación de su panteón religioso. Hecho que se expresa claramente en un testimonio:

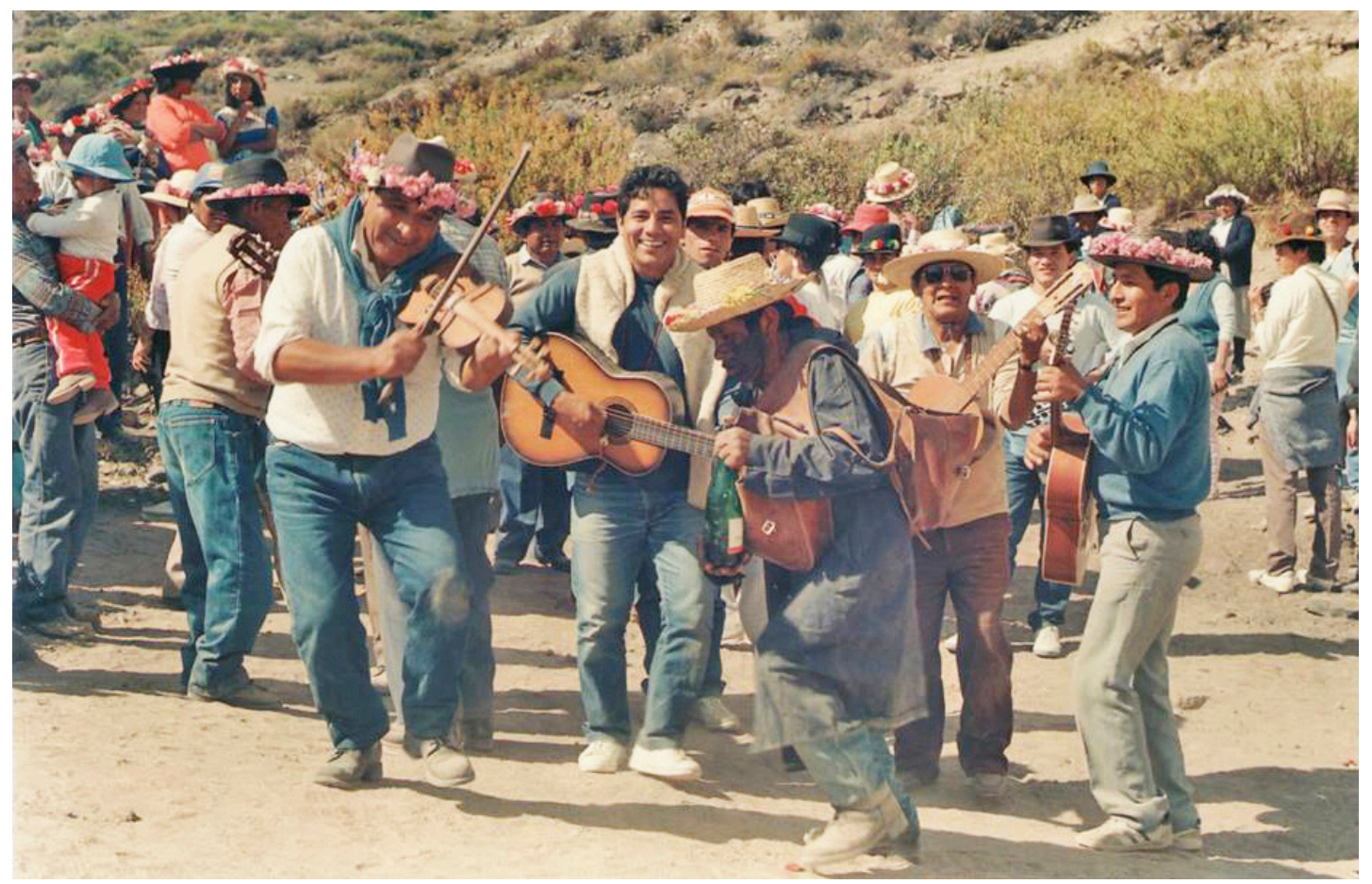

Figura 7. Guitarreros y "negro" cantando y bailando en la década de 1980.

"Black" singing and dancing in the 1980's and guitar makers. 


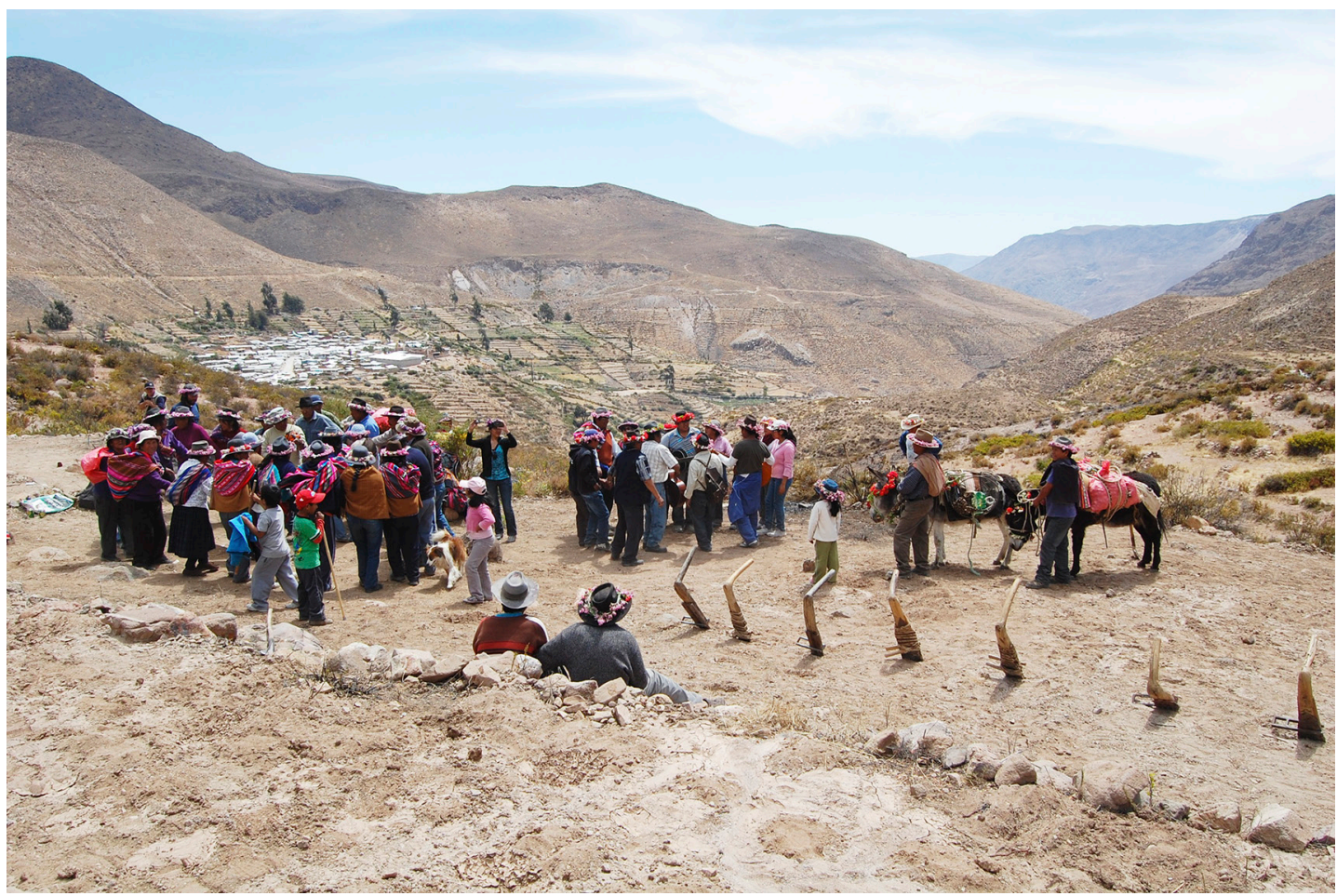

Figura 8. Mayordomos entrantes y salientes de la Virgen del Rosario bailando Pachallampe en Socoroma. Outgoing and incoming stewards of the Virgin of Rosario, dancing Pachallampe in Socoroma.

No olvido nunca cómo andaba la abuela Nieves Flores Vilca con su corona, su lliclia acá atravesado, con una lliclia elegante de esas que son originales, no de estos. Este no sirve, de esos originales tenían. Todos usaban sombreros de paño color plomo en Socoroma, así pasaban bonito nomás. No es como en Putre, allá es otra forma (Juana Gómez, 77 años).

Luego de la siembra simbólica, los mayordomos son reemplazados por la comunidad, quienes repiten con exactitud la escenificación previa. Mientras, los mayordomos se disponen a consumir la comida ritual típica, que ha sido preparada en la víspera del Pachallampe. El componente principal de los alimentos son la papa, cuya función culinaria es la estimulación de la fertilidad y la fecundidad de las chacras (Berg 1989), siendo consumida en sopas o cocidas y acompañadas de carne, mote de maíz y chuño, anteriormente fue costumbre preparar una watia o pachamanka en esta fecha ${ }^{38}$. Además las creencias andinas consideran que al alimentarse hombres y mujeres en las fiestas de siembra, también están alimentando a la tierra, dado el rol fecundador de ciertos ingredientes. Este acto facilita una secuencia de caminos de memoria o Amt'aña thakhi a medida que aumenta el consumo de alcohol entre los mayordomos (Choque 2013, 2015). El resultado de estas libaciones es la generación de memorias colectivas que tienen un despliegue emocional, que lleva a los actuantes a rememorar los espacios, temporalidades y escenarios jerarquizados de los linajes de la comunidad (Figura 9). Este hecho, es de suma importancia, pues el pasado les entrega constitución de identidad individual y colectiva, de ahí los esfuerzos en reescribir su memoria colectiva de manera permanente. Por lo tanto, el Pachallampe permite la construcción de significados culturales develados y desplegados dependiendo de los contextos sociales y rituales que van vivenciando los sujetos que están haciendo memoria (Figura 10). La asociación de identidad y memoria juega un rol fundamental en los grupos etarios más jóvenes de Socoroma, por dos consideraciones. Primero, los mayordomos requieren 
Segunda escena: Los comuneros

Concluida la siembra de los mayordomos ingresan a la chacra los comuneros (9), que son guiados por un par de Laritas (8), y "arreados" por el Lojo Lojo (2), quien supervisa el trabajo realizado. Finalmente, vienen las Küjgrarias (C), que van limpiando y reponiendo las Chipayas (surcos). El Awantiri tiene la función de semillas de papas (A) a los mayordomos y comuneros. Los servicios (B) están a cargo de convidar a los participantes de hojas de coca, vino, chicha y otros licores.

Primera escena: Los mayordomos

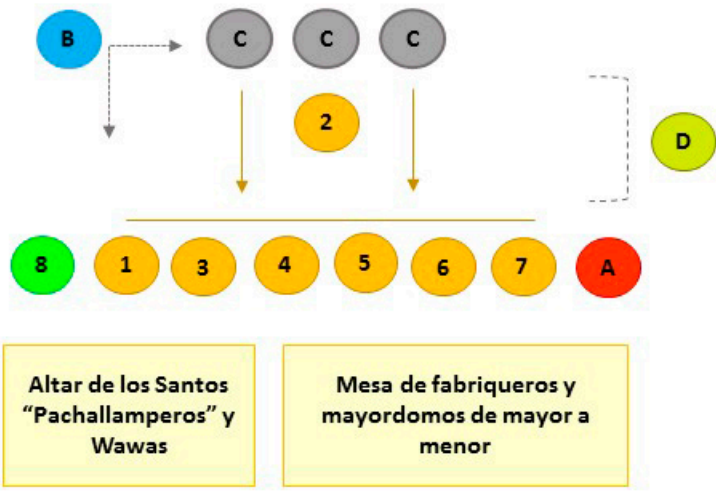

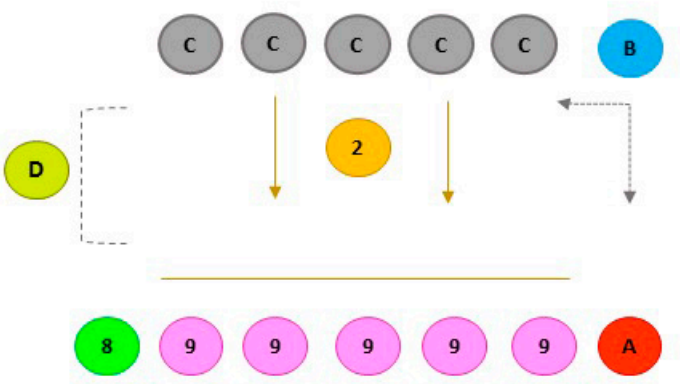

Mayordomos realizan siembra en representación de los santos patronos observador por el Fabriquero. Luego mayordomos y fabriqueros observan el trabajo de los comuneros mientras están en la mesa compartiendo la comida ritual.

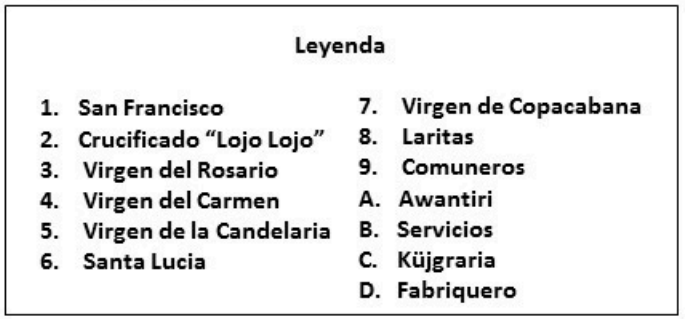

Figura 9. Estructura jerarquizada de siembra de papa en Socoroma.

Hierarchical structure of Socoroma potato planting.

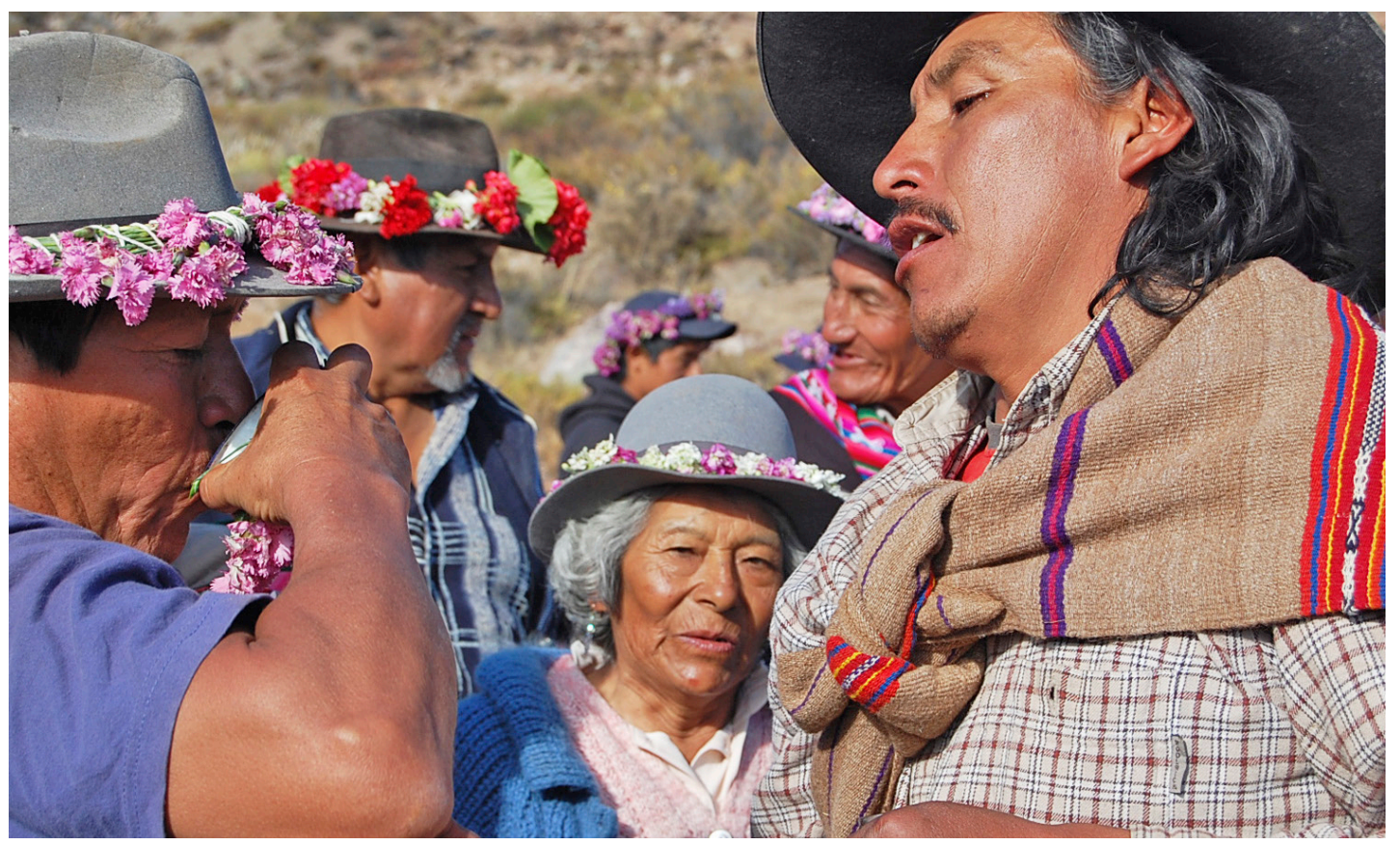

Figura 10. Libaciones de alcohol entre mayordomos y comuneros en Socoroma.

Libations of alcohol between stewards and community members in. 
de la participación masiva de los jóvenes, tanto por el despliegue de energía y laboriosidad como por las manifestaciones de sexualidad y cortejo entre hombres y mujeres, que vienen a nutrir el aumento de la fecundidad de la tierra (Barstow 1979). Segundo, porque la participación en el Pachallampe es el preámbulo para el desarrollo de la vida ritual entre los jóvenes solteros, ya que solo pueden participar de manera indirecta en otros ritos, además es un espacio de cortejo público, donde también se expresa la competencia por el prestigio social en la comunidad (Figuras 11 y 12).

\section{Comentario Final}

El Pachallampe es un rito agrícola que posee una dimensión de performance, narrativa y simbolismo, que da cuenta de los fuertes vínculos de la identidad y la memoria. Además, el despliegue ritual permite una secuencia jerarquizada de escenificaciones donde los sujetos actuantes pertenecen a la sociedad humana y extrahumana, hecho que explica el fuerte contenido emocional y efervescencia religiosa entre los socoromeños. Dicha situación no es exclusiva o singular, pues en las comunidades andinas de Ilabaya, Tarata y

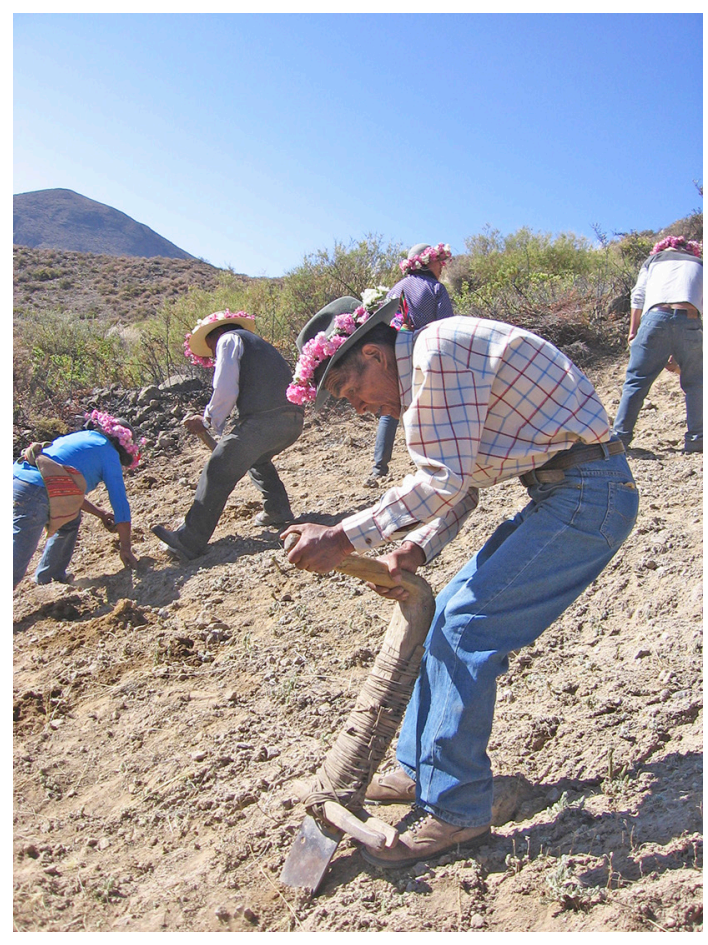

Figura 11. Mayordomos compitiendo con chaquitacllas o chontas en la siembra de la papa en Socoroma.

Stewards competing with chakitakllas or chontas in the planting of potato in Socoroma.

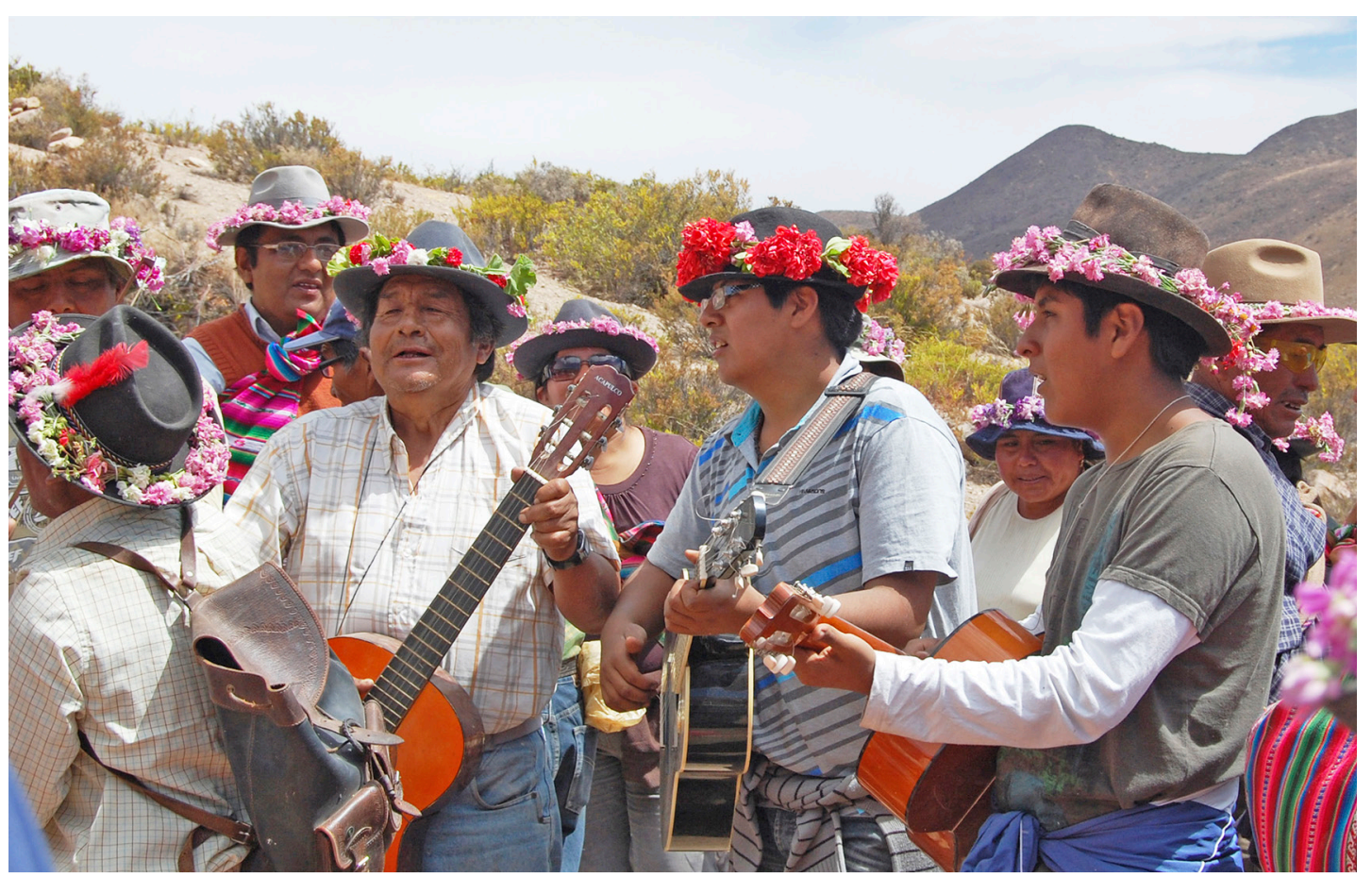

Figura 12. Guitarreros de Socoroma Neri Choque Mamani, Carlos y Alejandro Choque Manzano. Guitar makers of Socoroma Neri Choque Mamani, Carlos and Alejandro Choque Manzano. 
Candarave en los altos de Tacna se viven con la misma intensidad ${ }^{39}$, si bien en algunos casos no se presentan los mismos artefactos mnemotécnicos y tecnologías en los ritos, la finalidad sigue siendo la misma. Cabe destacar que las diferencias entre la fiesta de Papa Tarpuy y el Pachallampe en sus significados son escasas, pero sí podemos encontrar cambios en el despliegue performático y las dramatizaciones, pues en el caso de Socoroma el Pachallampe se ha nutrido de las expresiones musicales, jerarquizaciones sociales y religiosas del mundo tardo-colonial y republicano. Las expresiones rituales mediatizadas son el producto de la innovación y cambio cultural, constituyendo el imaginario colectivo de los andinos, que ven en sus ritos una expresión prístina de su identidad, que es rememorada y vivida permanentemente por hombres y mujeres, esto último producto de la activación de las huellas mnémicas que emergen en el contexto ritual y libatorio que se despliegan en la comunidad, y por lo tanto remantizada constantemente. Además, la danza y la música del Pachallampe son parte de las prácticas performativas, porque comprometen la acción y la experiencia de los sujetos a través de sus cuerpos, que manifiestan costumbres, acciones e identidades colectivas, que expresan una permanente interacción entre la subalternidad y las jerarquías hegemónicas de este mundo y el espacio sagrado a medida que se realiza esta fiesta polisémica.

Agradecimientos: Este artículo es producto de los proyectos Fondecyt $\mathrm{N}^{\circ} 11130024,1151138$, UTA MAYOR 5745-16 y Convenio de Desempeño UTA-Mineduc. Asimismo a los(as) evaluadores del manuscrito por sus valiosos comentarios que permitieron enriquecerlo. También, correspondemos a los vecinos de Socoroma: Teófilo Mario Choque, Justina Mariño, Yenny Manzano, Juana Gómez, José Flores, Freddy Gutiérrez, Rodrigo Huanca, Angélica Flores, Aydé Fernández, Joba Bernabé, Efraín Choque (Q.E.P.D), Eduardo Mayorga, Carlos Apata, Paulina Taboada, Adán Poma, María Carrasco, Liborio Gutiérrez (Q.E.P.D), Eusebio Marca, Rodomiro Huanca, Guillermina Quispe, Temístocles Poma y Neri Choque Mamani (Q.E.P.D), por su incalculable apoyo y conocimiento del Pachallampe. Asimismo, a Jorge Moreira, Carlos Choque Manzano, Erick Rodríguez, Alejandro Choque, Rodomiro Huanca, Alan Rodríguez, por sus fotografías, mapas y partituras musicales.

\section{Referencias Citadas}

Álvarez, L. 1987. El mito de Pusiri Collo y la fiesta del Pachallampe: aculturación andino-hispana en el poblado de Socoroma. Diálogo Andino 6:79-90.

Arce, M. 2014. Las Wankas de Espinar. Música Tradicional de la Región Cusco. Ministerio de Cultura - IFEA, Cusco.

Arnold, D. y J. Yapita 1996. Madre Melliza y sus Crías. Ispall Mama Wawampi. HISBOL-ILCA, La Paz.

Barstow, J.R. 1979. An Aymara Class Structure. Town and Community. University of Chicago Press, Chicago.

Berg, H. 1989. La Tierra No Da Así No Más. Editorial CEDLA, Amsterdam.

Bossert, F. y D. Villar 2006. Un problema de simbolismo: las máscaras y los muertos entre los Chañe. En Simbolismo, Ritual y Performance, editado por G. Wilde y P. Shamber, pp. 7-28. Ediciones Paradigma, Buenos Aires.

Brah, A. 1996. Cartographies of Diaspora: Contesting Identities. Routledge, London.

Buechler, H. y J. Buechler 1980. The Bolivian Aymara. Holt, Reinhard and Winston, New York.

Cachiguanco, L. 2002. El circulo círculo sagrado de la vida en los Andes Meridionales. Colección Altaen 693:25-44.

Canepa, G. 1998. Máscara, Transformación e Identidad en 1os Andes. Editorial PUCP, Lima.
Canepa, G. 2001. Identidades Representadas. Performance, Experiencia y Memoria en los Andes. Editorial PUCP, Lima.

Connerton, P. 1989. How Societies Remember. Cambridge University Press, Cambridge.

Corrales, E. 2004. El ritual de la cosecha de papa en la comunidad de Conde. Colección Altaen 684:4-44.

Chacama, J. y A. Díaz 2011. Cañutos y soplidos. Tiempo y cultura en las zampoñas de las sociedades precolombinas de Arica. Revista Musical Chilena LXV(216):34-57.

Choque, C. 2009. Divergencias y antagonismos del movimiento social indígena en la Región de Arica y Parinacota (1965-1985). Confluenze 1(2):267-289.

Choque, C. 2012a. Fortunato Manzano, el Último Yatiri. CONADI, Arica.

Choque, C. 2012b. Se Van los Peruanos... los más Testarudos se Quedan: Memoria y Olvido de la Chilenización en Socoroma. Tesis para obtener el grado de Doctor en Antropología-PUCP, Lima.

Choque, C. 2013. Amt'añ thakhi en Socoroma: Significado y expresiones del uso de la memoria en una comunidad aymara del norte de Chile. Confluenze 5(1):136-157.

Choque, C. 2015. Los Socoromas. Formas de Vida, Tecnología $y$ Religiosidad. CONADI, Arica. 
Choque, C. y E. Pizarro 2013. Identidades, continuidades y rupturas en el culto al agua y a los cerros en una comunidad andina de los altos de Arica. Estudios Atacameños 45:55-74.

Díaz, A. 2011. En la pampa los diablos andan sueltos. Demonios danzantes de la fiesta del santuario de La Tirana. Revista Musical Chilena LXV(216):58-97.

Díaz, A. 2014. Cofradías de Arica y Tarapacá en los siglos XVIII y XIX. Indígenas andinos, sistema de cargos religiosos y festividades. Revista de Indias LXXIV(260):101-128.

Díaz, A., L. Galdames y W. Muñoz 2012. Santos patronos en los andes. Imagen, símbolo y ritual en las fiestas religiosas del mundo andino colonial (siglos XVI-XVII). Alpha 35:23-39.

Eliade, M. 2001. El Mito de Eterno Retorno. Emecé Editores, Buenos Aires.

Fernández, G. 1995. El Banquete Aimara: Mesas y Yatiris. Hisbol, La Paz.

Gavilán, V. y A. Carrasco 2009. Festividades andinas y religiosidad en el norte chileno. Chungara Revista de Antropología Chilena 41:101-112.

Graves, C. 2006. La Papa Tesoro de los Andes. De la Agricultura a la Cultura. IPC, Lima.

Gundermann, H. 2004. Inicios de siglo en San Pedro de Atacama: Procesos, actores e imaginarios en una localidad andina. Chungara Revista de Antropología Chilena 36:221-239.

Hall, S. 1990. Cultural Identity and Diaspora. Ed. Lawrence \& Wishart, London.

Hayashida, F. 2008. Ancient beer and modern brewers: Ethnoarchaeological observations of chicha production in two regions of the North Coast of Peru. Journal of Anthropological Archaeology 27:161-174.

Henríquez, P. y M. Ostria 2015. Repertorio de prácticas escénicas de resistencia cultural. El Pachallampe. Alpha 41:191-205.

Hidalgo, J. 2004. Historia Andina en Chile. Editorial Universitaria, Santiago.

Jennings, J. y B.J. Bowser 2008. Drink, Power, and Society in the Andes. University Press of Florida, Gainesville.

Kus,. R. 1973. El Pensamiento Indígena y Popular en América. ICA, Buenos Aires.

Lacoste, P. 2004. La vid y el vino en América del Sur: el desplazamiento de los polos vitivinícolas (Siglos XVI al XX). Revista Universum 19(2):62-93.
Luque, M. 2009. Pachallampe. Fiesta patrimonial de la precordillera de Parinacota. Oralidad 16:70-75.

Mamani, M. 2002. El rito agrícola de Pachallampi y la música en Pachama, precordillera de Parinacota. Revista Musical Chilena LVI(198):45-62.

Medrano, S. 2007. Proceso de Elaboración de Chicha de Maíz (Zea mays): Caso Municipios de Punata, Cliza, Arbieto, Sipe Sipe, Tapacarí e Independencia del Departamento de Cochabamba. UMSS, Cochabamba.

Murra, J. 1968. La papa, el maíz y los ritos agrícolas del Tawantinsyu. Amaru 8:58-62.

Murra, J. 2002. El Mundo Andino. Población, Medio Ambiente y Economía. PUCP, Lima.

Pacheco, G. 2014. Producción de Chicha de Maíz en la Huaca San Marcos. UNMSM, Lima.

Plata, E. 2009. Léxicos aymaras relacionados con la siembra y cosecha de la papa. Colección Aalten 61:1-14.

Ochoa, V. 1975. Entierro y ritos a los difuntos. Boletín Ocasional 27:1-14.

Robles, R. 2007. El mensaje de los mitos: héroes fundadores y origen de los alimentos en la memoria de los pueblos andinos. Revista de Antropología 5:91-132.

Rosas, H. 1989. La Papa: Símbolo Andino de Vida. Museo de Antropología y Arqueología, Lima.

Sánchez, R. 2013. Simbolismo y ritualidad en torno a la papa en los Andes. Runa Yachachiy, I:1-28.

Sánchez-Monge, M. 1988. Investigación sobre la patata (Solanum tuberosum L.) en España (1933-1988). Anuario Aula Dei 19(1-2):45-54.

Sandoval, S. 2011. Chaupi ñamca: Takiscantari rumicunamanda huarmihuaca. Espaço Ameríndio 5(1):32-56.

Trueba, C. 2002. Ética y Tragedia en Aristóteles. UNAM, México D.F.

Valderrama, R. y C. Escalante 1993. Canciones de imploración y de amor en los Andes. Literatura oral de los quechuas del siglo XX. Revista de Crítica Literaria Latinoamericana XIX (37):11-39.

Van Kessel, J. y G. Cutipa 1998. El Marani de Chipukuni. IECTA, Iquique.

Van Kessel, J. y H. Larraín 2000. Manos Sabias para Criar la Vida. ABYA YALA, Quito.

\section{Notas}

1 El presente artículo es producto del proyecto Fondecyt $\mathrm{N}^{\circ} 11130024$ y 1151138 , UTA MAYOR 5745-16 y Convenio de Desempeño UTA-Mineduc.

2 Las comunidades del interior de Arica en las últimas décadas han adscrito a un horizonte étnico-cultural Aymara. Sin embargo, en el siglo XVI las poblaciones que habitaron el territorio adscribieron a identidades y lenguas Coles, Camanchacas, Urus y Aymaras, siendo esta última aquella que tuvo una mayor difusión y ampliación tras las aplicaciones de las ordenanzas del III Concilio Limense de fines del siglo XVI.

3 En el periodo colonial y republicano temprano las comunidades andinas que configuraron el Cacicazgo de Codpa constituyeron un espacio cultural y político llamado en diversos documentos e historiadores como los "Altos de Arica”, cuya versión homónima se localizó al interior de la ciudad de Tacna: Tarata e Ilabaya.

4 El mito personifica las transformaciones que ocurren en los espacios límites que ellas mismas representan y realzan 
el valor positivo del agua y la interioridad. Este mito de Huarochiri, en sus múltiples facetas representa el ciclo de la vida, la tipología del conocimiento cosmológico y sabiduría femenina.

5 El Alax Pacha, es el mundo de arriba o celestial, integrado por: Dios Creador (Sol Thunupa - Wiracocha), a Luna, el Rayo, las nubes y los Achachilas. Por otra parte, el Manqha pacha es el mundo de abajo, desconocido o lugar tenebroso donde habitan los espíritus malignos o negativos.

6 El ánimo (axayu), reside en el tallo y guía su crecimiento. El janayu, reside en las ramas de la planta, espacio físico escencial para la germinación de la papa. Finalmente, el ispíritu representa la esencia espiritual de la papa.

7 La acepción Pachallampe es un término que significa "con la tierra" o "en unión con la tierra".

8 Un reciente artículo publicado por Henríquez y Ostria, informa que las imágenes religiosas que participan del Pachallampe serían: "San Francisco, San Isidro, Virgen del Rosario y Corpus Cristi” (Henríquez y Ostria 2015:196). Dicha información no es correcta, pues ninguna imagen de los santos y vírgenes participa de forma directa en la fiesta, ya que solo participan los santos secundarios de sus altares como es el caso de San Isidro (adscrito a San Francisco), San Salvador (perteneciente a Virgen de la Candelaria) y los "niños" o "wawas" de las vírgenes del Rosario, Carmen y Santa Lucía. La mención al Corpus Christi igualmente es equivocada, pues posee su propia fiesta y está simbolizada por el Santísimo Sacramento.

$9 \quad$ El significado de Walichave proviene de la palabra Sata walichäwi que es arreglo o mejora de la siembra. También, sería una sustantivación del verbo walichaña (hacer bueno).

10 Baile colectivo en que participan hombres y mujeres, de carácter o función ritual agrícola del mes de mayo.

11 La chicha de maíz, según Pacheco (2014), es un producto de gran importancia en las diversas sociedades de la cultura andina, pues ha estado estrechamente relacionada al desarrollo cultural de las sociedades, siendo un elemento mágico religioso de relevancia económica y social.

12 Traducido al castellano es masticar.

13 Existe una copiosa información sobre el consumo de chica en Poma de Ayala y Juan de Betanzos.

14 El Pintatani, es una designación local dada al tipo de vino que se elabora en el valle de Codpa y Azapa desde la Colonia.

15 La producción y consumo del vino en el territorio se remonta a mediados del siglo XVI, dado que los señores indígenas e indios naturales tuvieron sus propias vides y cuyos productos eran destinados al consumo local y al mercado de Potosí.

16 La ch'onta es el arado de pie, que se denomina en el Perú como chaquitaclla.

17 En décadas pasadas eran lanzados "tiros" de dinamita desde el "Chorro" o acceso principal.

18 Ch'alta o ch'alla, nombre genérico del rito de libación de alcohol.

19 Cantos rituales agrícolas expresados en el sur del Perú y altiplano boliviano.

20 En el área andina los indígenas podían dialogar con el demonio como lo hacían con sus wakas, ídolos o antepasados, según los primeros registros de los evangelizadores del siglo XVI.

21 Dichas labores culturales se realizaban en junio y julio en décadas pasadas.

22 Sebo o grasa de animal.

23 Gerardo Fernández (1995) estableció que en las mesas aymaras son los dioses que comen a los afligidos; son los comensales sagrados los que devoran la aflicción representada metafóricamente en el plazo y, al hacerlo, propician, curan y limpian las carencias padecidas por los hombres.

24 Aroma, significa en castellano "Noche".

25 Otros sitios de siembra ritual están ubicados en el sector de Manqharuma o en el mismo pueblo.

26 En la última década se ha agregado al panteón de Socoroma, la imagen de la Virgen de Copacabana, que participa de los mismos ritos y dones en el Pachallampe y demás fiestas del pueblo.

27 En castellano "es un río pantanoso o lugares húmedos donde el agua es constante".

28 Las procesiones formaban parte de un acervo religioso público que rápidamente fue recepcionado por los indios desde una praxis agencial, dando como fruto una propia identidad religiosa católica.

29 Los "Servicios" son campesinos que han asumido el compromiso de colaborar recíprocamente o remunerada con el mayordomo para atender a vecinos, cuidar los animales, etc.

30 En el siglo XVIII habitan en la precordillera de Arica $90 \%$ de indígenas, originarios y forasteros; además de un pequeño porcentaje de población de otras castas, entre las cuales se encontraban los negros, mulatos y zambaigos. Por tanto, no fue extraño que en el pueblo de Socoroma, hubiese un número reducido de esclavos al igual que en otras comunidades andinas, pues en 1773 se registran dos esclavas adultas y un niño que probablemente era esclavo. En Sora se registraron dos mulatos, aunque en otros registros estas mismas personas fueron identificadas como "monstruncos". En 1763 fue bautizada María Mercedes, hija legítima de Manuel Yañez y Basilia Puis, monstruncos; y posteriormente, en 1766, fue bautizado Juan, hijo legítimo de Manuel Yañez y Basilia Catorceno, ambos mulatos (Díaz 2012).

31 Ver también el trabajo de Manuel Mamani (2002). Adicionalmente, se debe tener en cuenta que las comunidades andinas asocian lo "negro" con la noche, pero también "pareja, ayuda, ayudante y complemento", siendo parte de una totalidad, que no puede desprenderse del tiempo y espacio sagrado. Lo negro, por tanto, es parte de la dualidad del hombre andino.

32 El "indio" colonial busca terminar las categorías de sujeción tributaria y jurídica impuesta.

33 Este instrumento es de una gran antigüedad y se lo utiliza más que nada para medir el peso de la mercancía como el orégano o papa, antes de ser vendida a los compradores.

34 La Lliclla o lliclia, es manta tejida que llevan las mujeres en los Andes con múltiples usos. Suele ser muy colorida con motivos, patrones, tamaños y colores que varían de acuerdo a la región.

35 La historia del acordeón es corta pero rápida e intensa, de tal suerte que registró el invento como acordión en 1829 , expandiéndose más tarde al mundo andino a fines del siglo XIX e inicios del XX.

36 Mamani (2002), identificó en Pachama el uso de quenas y charango en sus estudios.

37 Laritas (Guía la siembra), awantiri (cargadores de papa o cargueros), lojo lojo o "arriero" (mayordomo que supervisa la siembra y el ritual performatizado) y kullakas (mujeres que reparan las contras y sistema de riego).

38 Comida ritual de tiempos de cosecha.

39 En los pueblos de Tarata, Candarave e Ilabaya en los meses de siembra de papa, de octubre a diciembre, se realizan ritos festivos donde los hombres llevan chaquitacllas y las mujeres lliclias y coronas de flores, muy similares a los identificados en Socoroma y Pachama. 